\title{
Influence of Maternal Stress during Pregnancy on Child's Neurodevelopment
}

\author{
Cristina Matas-Blanco * and Rafael A. Caparros-Gonzalez \\ Department of Nursing, University of Granada, 18010 Granada, Spain; rcg477@ugr.es \\ * Correspondence: cristina-matas@hotmail.com
}

Received: 19 August 2020; Accepted: 13 October 2020; Published: 16 October 2020

check for updates

\begin{abstract}
Background: High stress levels during pregnancy can affect the organogenesis and the foetus' central nervous system maturation. The objective of this study was to determine whether a relationship between maternal stress during pregnancy and alterations in child neurodevelopment exists; (2) Methods: A bibliographical review was carried out following PRISMA Methodology and using Scopus, Web of Science and Cinahl databases. The research questions were made using PEO methodology (Participants, Exposition, Outcomes). Moreover, article quality was measured using the Quality Assessment Tool for Observational Cohort and Cross-Sectional Studies; (3) Results: 22 articles that fit the inclusion criteria were selected. Different elements altered because of maternal stress during pregnancy could side with alterations in different areas of the neurodevelopment, such as cognitive development, motor development, behaviour, temperament, memory and learning abilities; (4) Conclusions: Although maternal stress can have an influence on children's neurodevelopment, it is still unknown which are the specific elements related to this stress that can modify it negatively. Furthermore, future studies should evaluate whether a sex-specific association exists.
\end{abstract}

Keywords: pregnancy; psychological stress; foetal development; child behaviour disorders; learning; cognition

\section{Introduction}

Around $78 \%$ of women experience moderate levels of stress during pregnancy, while around $6 \%$ can experience high levels [1]. The American Institute of Stress defines stress as "a condition or feeling experienced when a person perceives that demands exceed the personal and social resources the individual is able to mobilise" [2]. Women suffering from stress during pregnancy are related to a major risk of child prematurity, low birth weight or problems related to learning in their children [1].

During pregnancy, women usually suffer from stress due to different causes, such as owning low resources, unfavourable working conditions, possible complications during pregnancy, responsibilities at home and arguing with their partner [1]. These problems are very common in developed countries' lifestyle, which is the reason why it is necessary to check if stress can influence foetal neurodevelopment to establish ways to control it. Foetal neurodevelopment consists of a sequence of complex mechanisms which lead to the normal development of the foetus' central nervous system (CNS), including neurogenesis, cellular migration, molecular specification, myelination and synaptogenesis [3]. These mechanisms are not just important during gestation, but also after it [4] and due to their complexity, the development of the CNS is very vulnerable to stress, pesticide exposition, teratogens and prematurity $[3,4]$.

Besides general stress, there is also a pregnancy-specific stress, which is related to the fears of the mother about the baby's health and well-being, labour process, postpartum and the future role as a mother [5]. A relation between pregnancy-specific stress and postpartum depression, low birth weight and a reduction in anthropometric development has been found $[1,6]$. 
The main biological cause able to affect the foetus coming from women's psychological stress is an excess of cortisol produced by her organism [7]. Those high levels can be measured through a hair or saliva sample from the mother $[1,8]$.

The hormone $11 \beta$-hydroxysteroid dehydrogenase type 2 is found in the placenta. It is able to deactivate $90 \%$ of maternal cortisol going through it [7]. However, in acute or chronic stress situations, it decreases its ability to protect the foetus' hypothalamic-pituitary-adrenal axis (HPAA), which holds an essential role in brain maturation [7]. It can decrease the number of hippocampus receptors for corticosteroids [9]. Moreover, the excess of maternal cortisol can bring to low cortisol levels in the extrauterine life of the foetus, requiring the administration of exogenous glucocorticoids [8].

Aside from this cortisol transference, evidence showing that maternal cortisol can stimulate the placenta for producing corticotropin-releasing hormone (CRH) has been found [7]. This hormone will go from the mother to the foetal circulation, stimulating cortisol production in both of them [7]. However, besides cortisol, other mediators also have an influence on the foetus. For example, catecholamines, which can reduce blood flow in the uterus affecting general development, or serotonin, which is very important for the brain's right development [7].

The effect of perinatal stress on the foetus depends on the exposition time [7] and the moment of pregnancy, being more harmful early in pregnancy [10] because it can lead to changes in behaviour, psychomotor development and exploration [10]. When stress appears later in pregnancy, it could lead to alterations in character development and a lower psychomotor development $[9,10]$. Furthermore, it could cause brain changes similar to those observed in cerebral palsy [11].

However, these previous research studies could not find a clear correlation between maternal stress during gestation and future problems in the foetus' neurodevelopment. In this way, the main objective of this study was to determine whether the said correlation exists.

\section{Materials and Methods}

This bibliographical review started with the selection of articles, using for that purpose the PRISMA Methodology (Preferred Reporting Items for Systematic Reviews and Meta-Analysis) [12], which allows us to perform an exhaustive searching. The used databases were Scopus, Web of Science and Cinahl. Aiming to perform a precise searching, PEO methodology was used as well. It allows us to write the research questions by identifying three different parts: participants, exposition and outcomes. In this review, the following research questions were used:

gestation AND pregnancy-specific stress AND neurodevelopment pregnancy AND pregnancy-specific stress AND neurodevelopment pregnancy AND maternal stress AND neurodevelopment

The inclusion criteria were that the articles were written in English or Spanish, they were original texts, observational studies, experimental studies, case-control studies, longitudinal or transversal studies, full text available and published within the last 10 years.

The exclusion criteria included that the articles were editor's letters or opinion articles.

Moreover, in some databases, more criteria were used:

- Scopus: searching from title and abstract.

- Web of Science: search included in reproductive biology, behavioural sciences, neurosciences, obstetrics and gynaecology, paediatrics, psychology and psychiatry.

For the final selection of the articles, firstly, all studies found in databases that reached the criteria were selected. Later, duplicated studies and those which did not talk about the subject were excluded. Finally, all articles remaining were read to verify they fitted the inclusion criteria. Moreover, two articles were chosen from the references list of some of the selected research. All the steps followed to obtain the final articles are summarised in Figure 1: Methodology. 


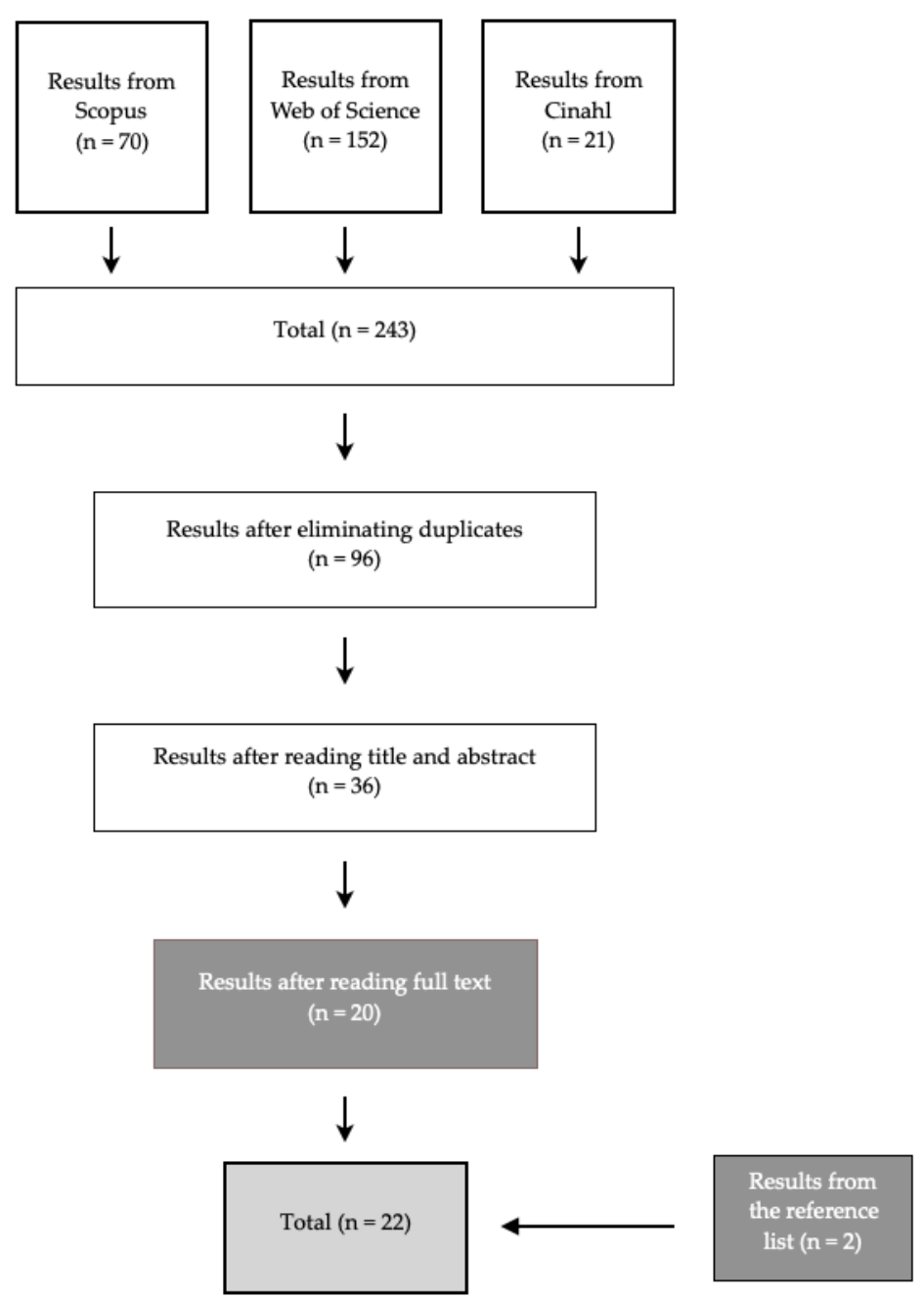

Figure 1. Methodology.

The quality of the chosen articles was evaluated with the Quality Assessment Tool for Observational Cohort and Cross-Sectional Studies Tool [13]. It is a questionnaire with 14 questions which helps to measure a study's internal validity. The questions can be answered with "Yes", "No" or "Not applicable". This questionnaire evaluates the objectives, population, exposition measures and results.

\section{Results}

This revision included 22 articles that helped in studying the relationship between maternal stress during pregnancy and neurodevelopment. They are described in Table 1: Results. During stress situations, the HPAA releases high levels of cortisol [14]. It is also important the role placental hormones play [14], not allowing high levels of cortisol going through the placenta. This function can be reduced during stress situations [14]. Furthermore, other investigators proposed more factors that can be modified because of stress and may have an influence on neurodevelopment:

- Maternal microbiome, which intervenes in the colonisation of the foetus' gut, setting up the gut-brain axis $[14,15]$. The gut-brain axis is an innovative perspective able to regulate the development of the CNS. Stress can destabilise the maternal microbiome, which will also affect the foetus' microbiome $[14,16]$.

- Nutrition, due to the capacity of stress to affect the perception of hunger, satiation and food preferences [17]. This can also modify intrauterine development [17].

- Sleep, which is able to disrupt the circadian cycle, interfering in hormonal release [14]. 
Table 1. Results.

\begin{tabular}{|c|c|c|c|c|c|c|}
\hline \multicolumn{7}{|c|}{ RESULTS } \\
\hline Title & Main Author. Year & Country & Studied Area & $\begin{array}{l}\text { Stress Levels } \\
\text { Measurement }\end{array}$ & Results & Quality \\
\hline $\begin{array}{c}\text { Mechanisms underlying the effects } \\
\text { of prenatal psychosocial stress on } \\
\text { child outcomes: beyond the HPA } \\
\text { axis }\end{array}$ & $\begin{array}{l}\text { Beijers R. } \\
2014\end{array}$ & Germany & $\begin{array}{l}\text { Hypothalamic-pituitary- } \\
\text { adrenal axis }\end{array}$ & Cortisol levels in saliva & $\begin{array}{l}\text { Because of pregnancy-specific } \\
\text { stress, different altered elements } \\
\text { can influence the foetus' } \\
\text { neurodevelopment. }\end{array}$ & Fair \\
\hline $\begin{array}{c}\text { Alterations in the Vaginal } \\
\text { Microbiome by Maternal Stress } \\
\text { Are Associated with Metabolic } \\
\text { Reprogramming of the Offspring } \\
\text { Gut and Brain }\end{array}$ & $\begin{array}{l}\text { Jasarevic E. } \\
\quad 2015\end{array}$ & $\begin{array}{l}\text { United } \\
\text { States of } \\
\text { America }\end{array}$ & Brain development & Cortisol levels in blood & $\begin{array}{l}\text { Maternal stress can disregulate her } \\
\text { vaginal microbiome, which can } \\
\text { lead to inappropriate brain } \\
\text { development after birth. }\end{array}$ & Good \\
\hline $\begin{array}{l}\text { The Interplay Between Nutrition } \\
\text { and Stress in Pregnancy: } \\
\text { Implications for Fetal } \\
\text { Programming of Brain } \\
\text { Development }\end{array}$ & $\begin{array}{l}\text { Lindsay K. } \\
\quad 2019\end{array}$ & $\begin{array}{l}\text { United } \\
\text { States of } \\
\text { America }\end{array}$ & Brain development & Cortisol levels in blood & $\begin{array}{c}\text { Diet can be modified in stress } \\
\text { situations and that can affect fetal } \\
\text { neurodevelopment during } \\
\text { pregnancy. }\end{array}$ & Good \\
\hline $\begin{array}{l}\text { Maternal pregnancy-specific } \\
\text { anxiety is associated with child } \\
\text { executive function at } 6-9 \text { years age }\end{array}$ & $\begin{array}{l}\text { Buss C. } \\
2011\end{array}$ & $\begin{array}{l}\text { United } \\
\text { States of } \\
\text { America }\end{array}$ & $\begin{array}{l}\text { Executive functions } \\
\text { Cognitive development } \\
\text { Visuospatial memory }\end{array}$ & $\begin{array}{l}\text { 10-item scale of } \\
\text { pregnancy-specific stress } \\
\text { (especially developed for } \\
\text { this study) } \\
\text { State-Trait Anxiety } \\
\text { Inventory (STAI) }\end{array}$ & $\begin{array}{l}\text { Pregnancy-specific stress can } \\
\text { decrease prefrontal cortex's and } \\
\text { hippocampus' gray matter, } \\
\text { affecting executive functions and } \\
\text { visuospatial memory. }\end{array}$ & Good \\
\hline $\begin{array}{c}\text { Evening salivary cortisol and } \\
\text { alpha-amylase at } 14 \text { months and } \\
\text { neurodevelopment at } 4 \text { years: sex } \\
\text { differences }\end{array}$ & $\begin{array}{c}\text { Andiarena A. } \\
2017\end{array}$ & Spain & $\begin{array}{l}\text { Executive functions } \\
\text { Cognitive development } \\
\text { Motor development }\end{array}$ & $\begin{array}{l}\text { Cortisol levels in saliva } \\
\text { State-Trait Anxiety } \\
\text { Inventory (STAI) }\end{array}$ & $\begin{array}{l}\text { High maternal cortisol levels are } \\
\text { correlated to alterations in } \\
\text { executive function, motor } \\
\text { development and cognitive } \\
\text { development. }\end{array}$ & Good \\
\hline $\begin{array}{l}\text { Maternal alexithymic traits, } \\
\text { prenatal stress, and infant } \\
\text { temperament }\end{array}$ & $\begin{array}{l}\text { Kantonen T. } \\
\quad 2015\end{array}$ & Finland & $\begin{array}{l}\text { Cognitive development } \\
\text { Motor development }\end{array}$ & $\begin{array}{l}\text { Pregnancy-Related } \\
\text { Anxiety questionnaire } \\
\text { revised (PRAQ) }\end{array}$ & $\begin{array}{l}\text { Pregnancy-specific stress could } \\
\text { alter children psycomotor } \\
\text { development and cognitive } \\
\text { development. }\end{array}$ & Fair \\
\hline $\begin{array}{c}\text { Prenatal maternal stress, fetal } \\
\text { programming, and mechanisms } \\
\text { underlying later } \\
\text { psychopathology-A global } \\
\text { perspective }\end{array}$ & $\begin{array}{l}\text { Glover V. } \\
2018\end{array}$ & $\begin{array}{l}\text { United } \\
\text { Kingdom }\end{array}$ & Cognitive development & $\begin{array}{l}\text { Cortisol levels in } \\
\text { amniotic fluid }\end{array}$ & $\begin{array}{l}\text { High cortisol levels in amniotic } \\
\text { fluid can be related to lower scores } \\
\text { according to cognition in Bayle } \\
\text { Scales of Infant Development. }\end{array}$ & Good \\
\hline
\end{tabular}


Table 1. Cont

\begin{tabular}{|c|c|c|c|c|c|c|}
\hline \multicolumn{7}{|c|}{ RESULTS } \\
\hline Title & Main Author. Year & Country & Studied Area & $\begin{array}{l}\text { Stress Levels } \\
\text { Measurement }\end{array}$ & Results & Quality \\
\hline $\begin{array}{l}\text { Prenatal development origins of } \\
\text { behavior and mental health: The } \\
\text { influence of maternal stress in } \\
\text { pregnancy }\end{array}$ & $\begin{array}{c}\text { Van den Bergh B. } \\
2017\end{array}$ & Belgium & Cognitive development & $\begin{array}{c}\text { Perceived Stress Scale } \\
\text { (PSS) } \\
\text { Cortisol levels in plasma }\end{array}$ & $\begin{array}{l}\text { Maternal stress during pregnancy } \\
\text { can alter cognitive development in } \\
\text { children. }\end{array}$ & Good \\
\hline $\begin{array}{c}\text { Maternal and Neonatal Hair } \\
\text { Cortisol Levels Are Associated } \\
\text { with Infant Neurodevelopment at } \\
\text { Six Months of Age }\end{array}$ & $\begin{array}{c}\text { Caparros-González R. } \\
2019\end{array}$ & Spain & $\begin{array}{l}\text { Cognitive development } \\
\text { Motor development }\end{array}$ & $\begin{array}{l}\text { Cortisol levels in the } \\
\text { mother's hair }\end{array}$ & $\begin{array}{l}\text { High cortisol levels in the mother's } \\
\text { hair during first and second } \\
\text { trimester of pregnancy can be } \\
\text { related to a lower motor } \\
\text { development. }\end{array}$ & Good \\
\hline $\begin{array}{l}\text { Positive maternal mental health } \\
\text { during pregnancy associated with } \\
\text { specific forms of adaptive } \\
\text { development in early childhood: } \\
\text { Evidence from a longitudinal study }\end{array}$ & $\begin{array}{c}\text { Phua D. } \\
2017\end{array}$ & Singapore & Behaviour & $\begin{array}{c}\text { State-Trait Anxiety } \\
\text { Inventory (STAI) } \\
\text { Anxiety sub-scale } \\
\text { Crown-Crisp Experiential } \\
\text { Index }\end{array}$ & $\begin{array}{l}\text { Positive mental health during } \\
\text { pregnancy can be positive for the } \\
\text { foetus' development in social } \\
\text { behaviour and communication. }\end{array}$ & Good \\
\hline $\begin{array}{l}\text { Maternal Cortisol Concentrations } \\
\text { During Pregnancy and Sex-Specific } \\
\text { Associations With Neonatal } \\
\text { Connectivity and Emerging } \\
\text { Internalizing Behaviors }\end{array}$ & $\begin{array}{l}\text { Graham A. } \\
2019\end{array}$ & $\begin{array}{l}\text { United } \\
\text { States of } \\
\text { America }\end{array}$ & Behaviour & Cortisol levels & $\begin{array}{l}\text { High maternal cortisol levels can } \\
\text { influence the connection between } \\
\text { the foetal amygdala with other } \\
\text { brain structures, being negative to } \\
\text { the future behaviour and learning } \\
\text { abilities. }\end{array}$ & Good \\
\hline $\begin{array}{l}\text { Prenatal programming of stress } \\
\text { responsiveness and behaviors: } \\
\text { Progress and perspectives }\end{array}$ & $\begin{array}{l}\text { Hamada H. } \\
2018\end{array}$ & Canada & $\begin{array}{c}\text { Behavior } \\
\text { Learning abilities }\end{array}$ & $\begin{array}{l}\text { Scale designed for this } \\
\text { study }\end{array}$ & $\begin{array}{l}\text { Maternal stress during pregnancy } \\
\text { can affect the future behaviour in } \\
\text { children, but there will be } \\
\text { sex-specific differences. }\end{array}$ & Good \\
\hline $\begin{array}{l}\text { Prenatal psychobiological } \\
\text { predictors of anxiety risk in } \\
\text { preadolescent children }\end{array}$ & $\begin{array}{c}\text { Davis E. } \\
2011\end{array}$ & $\begin{array}{l}\text { United } \\
\text { States of } \\
\text { America }\end{array}$ & Behaviour & $\begin{array}{l}\text { Cortisol levels in saliva } \\
\text { Perceived Stress Scale } \\
\text { (PSS) } \\
\text { State-Trait Anxiety } \\
\text { Inventory (STAI) } \\
\text { 10-item } \\
\text { Pregnancy-Related } \\
\text { Anxiety scale }\end{array}$ & $\begin{array}{l}\text { Pregnancy-specific stress could be } \\
\text { directly related to the development } \\
\text { of anxious states in preadolescents. }\end{array}$ & Good \\
\hline
\end{tabular}


Table 1. Cont

\begin{tabular}{|c|c|c|c|c|c|c|}
\hline \multicolumn{7}{|c|}{ RESULTS } \\
\hline Title & Main Author. Year & Country & Studied Area & $\begin{array}{l}\text { Stress Levels } \\
\text { Measurement }\end{array}$ & Results & Quality \\
\hline $\begin{array}{l}\text { Maternal exposure to psychosocial } \\
\text { job strain during pregnancy and } \\
\text { behavioral problems in the } \\
\text { 11-year-old children: a Danish } \\
\text { cohort study. }\end{array}$ & $\begin{array}{l}\text { Sejbaek C. } \\
2020\end{array}$ & Denmark & Behaviour & $\begin{array}{l}\text { Questions about } \\
\text { psychosocial job strain } \\
\text { during interviews }\end{array}$ & $\begin{array}{l}\text { Mothers who are affected by job } \\
\text { stress are more likely to have } \\
\text { children with hyperactivity and/or } \\
\text { emotional problems. }\end{array}$ & Good \\
\hline $\begin{array}{l}\text { Higher Maternal Prenatal Cortisol } \\
\text { and Younger Age Predict Greater } \\
\text { Infant Reactivity to Novelty at } 4 \\
\text { Months: An Observation-Based } \\
\text { Study }\end{array}$ & $\begin{array}{l}\text { Werner E. } \\
2013\end{array}$ & $\begin{array}{l}\text { United } \\
\text { States of } \\
\text { America }\end{array}$ & Behaviour & $\begin{array}{c}\text { Cortisol levels in saliva } \\
\text { State-Trait Anxiety } \\
\text { Inventory (STAI) } \\
\text { Perceived Stress Scale } \\
\text { (PSS) }\end{array}$ & $\begin{array}{l}\text { High levels of cortisol during the } \\
\text { third trimester of pregnancy can be } \\
\text { correlated with behaviour } \\
\text { alterations during the first months } \\
\text { of life. }\end{array}$ & Good \\
\hline $\begin{array}{l}\text { Prenatal anxiety, maternal stroking } \\
\text { in infancy, and symptoms of } \\
\text { emotional and behavioral } \\
\text { disorders at } 3.5 \text { years }\end{array}$ & $\begin{array}{l}\text { Pickles A. } \\
2017\end{array}$ & $\begin{array}{l}\text { United } \\
\text { Kingdom }\end{array}$ & Behaviour & $\begin{array}{l}\text { Pregnancy-Specific } \\
\text { Anxiety Scale } \\
\text { State-Trait Anxiety } \\
\text { Inventory (STAI) }\end{array}$ & $\begin{array}{l}\text { The correlation between } \\
\text { pregnancy-specific stress and } \\
\text { future behaviour problems in } \\
\text { children could be reduced by the } \\
\text { influence of maternal stroking. }\end{array}$ & Good \\
\hline $\begin{array}{l}\text { Maternal antenatal anxiety, } \\
\text { postnatal stroking and emotional } \\
\text { problems in children: outcomes } \\
\text { predicted from pre- and postnatal } \\
\text { programming hypotheses }\end{array}$ & $\begin{array}{l}\text { Sharp H. } \\
2015\end{array}$ & $\begin{array}{l}\text { United } \\
\text { Kingdom }\end{array}$ & Behaviour & $\begin{array}{l}\text { State-Trait Anxiety } \\
\text { Inventory (STAI) }\end{array}$ & $\begin{array}{l}\text { Maternal stroking after birth could } \\
\text { revert the negative effects on } \\
\text { behaviour pregnancy-specific } \\
\text { stress can cause, especially in girls. }\end{array}$ & Fair \\
\hline $\begin{array}{l}\text { The role of maternal emotional } \\
\text { states during pregnancy and early } \\
\text { infancy on infant cortisol levels: A } \\
\text { prospective study }\end{array}$ & $\begin{array}{c}\text { Hernández-Martínez } \\
\text { C. } \\
2019\end{array}$ & Spain & Behaviour & $\begin{array}{c}\text { Questionnaires } \\
\text { Blood samples (serum) }\end{array}$ & $\begin{array}{l}\text { Maternal stress can be related to } \\
\text { difficulties in establishing the } \\
\text { mother-son bond. }\end{array}$ & Fair \\
\hline $\begin{array}{l}\text { Influence of prenatal maternal } \\
\text { stress, maternal plasma cortisol } \\
\text { and cortisol in the amniotic fluid } \\
\text { on birth incomes and child } \\
\text { temperament at } 3 \text { months }\end{array}$ & $\begin{array}{l}\text { Baibazarova E. } \\
2013\end{array}$ & $\begin{array}{l}\text { The } \\
\text { Netherlands }\end{array}$ & Temperament & Blood samples (serum) & $\begin{array}{l}\text { Maternal perceived stress is related } \\
\text { to difficult temperament in } \\
\text { children. }\end{array}$ & Good \\
\hline
\end{tabular}


Table 1. Cont

\begin{tabular}{|c|c|c|c|c|c|c|}
\hline \multicolumn{7}{|c|}{ RESULTS } \\
\hline Title & Main Author. Year & Country & Studied Area & $\begin{array}{l}\text { Stress Levels } \\
\text { Measurement }\end{array}$ & Results & Quality \\
\hline $\begin{array}{l}\text { Prenatal maternal anxiety and } \\
\text { early childhood temperament }\end{array}$ & $\begin{array}{c}\text { Blair M. } \\
2011\end{array}$ & $\begin{array}{l}\text { The } \\
\text { Netherlands }\end{array}$ & Temperament & $\begin{array}{l}\text { State-Trait Anxiety } \\
\text { Inventory (STAI) } \\
\text { 10-item } \\
\text { Pregnancy-Related } \\
\text { Anxiety Scale }\end{array}$ & $\begin{array}{c}\text { Pregnancy-specific stress } \\
\text { influencies temperament } \\
\text { development in children during } \\
\text { their first years of life, being more } \\
\text { harmful when it shows earlier in } \\
\text { pregnancy. }\end{array}$ & Good \\
\hline $\begin{array}{c}\text { Pregnancy-specific anxiety, ART } \\
\text { conception and infant } \\
\text { temperament at } 4 \text { months } \\
\text { postpartum }\end{array}$ & $\begin{array}{l}\text { McMahon C. } \\
\quad 2013\end{array}$ & Australia & Temperament & $\begin{array}{c}\text { State-Trait Anxiety } \\
\text { Inventory (STAI) } \\
\text { Anxiety concerning } \\
\text { Health and Defects in the } \\
\text { Child scale (Baby Schema } \\
\text { questionnaire) }\end{array}$ & $\begin{array}{l}\text { Pregnancy-specific stress during } \\
\text { third trimester is not correlated to } \\
\text { the development of a difficult } \\
\text { temperament in children. }\end{array}$ & Good \\
\hline $\begin{array}{l}\text { Prenatal maternal factors in the } \\
\text { development of cognitive } \\
\text { impairments in the offspring }\end{array}$ & $\begin{array}{l}\text { Richetto J. } \\
2014\end{array}$ & Italy & $\begin{array}{c}\text { Memory } \\
\text { Learning abilities }\end{array}$ & $\begin{array}{l}\text { CRH levels in maternal } \\
\text { blood }\end{array}$ & $\begin{array}{l}\text { Maternal stress can negatively } \\
\text { affect memory and learning } \\
\text { abilities due to structural } \\
\text { alterations in the hippocampus. }\end{array}$ & Fair \\
\hline
\end{tabular}


For a better organisation of the results, they are presented in different sections according to the studied area of the neurodevelopment.

\subsection{Cognitive Development}

Pregnancy-specific stress can influence the development of the foetus' brain even more than general stress [18]. It can affect the executive function due to a reduction of the prefrontal cortex's grey matter [18,19]. This can modify the development of cognitive capacities [20]. Moreover, slower rates of mental development measured using the Bayley Scales of Infant Development were related to higher cortisol levels in amniotic fluid [15]. Moreover, higher levels of cortisol measured in maternal saliva were related to lower cognitive development at 4 years old [19].

When studying the relationship between maternal stress during pregnancy and long-term cognitive development, it was affirmed that an excess of cortisol in the foetal brain can damage myelin sheaths in the CNS, which will cause problems related to low cognitive development during adolescence [21]. Specifically, this relation was stronger when the mother experienced higher levels of stress between 12-22 weeks of pregnancy, but not after that period [21].

It was also exposed that girls are more vulnerable to suffer from side effects coming from their mothers' stress, mostly when it appears during the first trimester of pregnancy [18]. This could happen because that period is more vulnerable to the action of stress over the foetal brain [18].

Other authors theorised that pregnancy-specific stress and general stress during pregnancy does not always need to have a negative impact, because in some cases it could accelerate cognitive development [22].

\subsection{Motor Development}

Some authors focused their investigations in this area, concluding that higher levels of cortisol found in the mother's hair during the first and second trimester of pregnancy can be associated with a lower motor development [22]. This could be due to the effects of glucocorticoids over the cerebellar function $[19,20]$. Moreover, sex-specific differences were found in some cases, with girls being more affected than boys [19,22].

\subsection{Behaviour}

The influence of positive mental health during pregnancy was studied using a screening tool: the State-Trait Anxiety Inventory (STAI) and the Anxiety Sub-Scale Crown-Crisp Experiential Index, concluding that positive mental health can improve social behaviour [23].

Acute stress can cause anatomic and functional modifications related to alterations in behaviour [24,25], future conduct disorders [24,25] and the development of anxious states during preadolescence [26].

Other studies measured stress levels at work in relation with behaviour alterations. They were rated by the mothers and the children's teachers as well, showing a little increase in the odds of emotional problems and hyperactivity in boys and emotional problems in girls [27].

The effect of this stress on behaviour will depend on the moment of pregnancy, the intensity and mostly on the foetal sex [25]. Each research shows different results in relation to the most vulnerable period of pregnancy: on one hand, some studies affirm that it should appear at the beginning [25]; on the other hand, other studies conclude that there will be more alterations when it appears on the last trimester [28]. Small sex-specific differences were also observed, explaining that boys were more likely to suffer from hyperactivity and emotional problems, while girls would mainly experience emotional problems [27].

Additionally, some studies show that the negative effects on behaviour that can be caused by maternal stress can be reversed by the action of mother's stroking during the first 9 months of life $[29,30]$, having higher positive effects on girls [30]. The most important factors for establishing a nice mother-son bond are breastfeeding and skin-to-skin contact [30]. However, maternal stress 
during gestation could be related to difficulties in establishing this mother-son bond. This could also affect children's HPAA, because of a modification in the accumulative effect of its development [31].

\subsection{Temperament}

During an investigation, maternal stress during pregnancy and cortisol levels in her organism were measured, showing that temperament alterations in children were mostly related to psychological stress perceived by the mother, but not so much with cortisol levels in plasma [32,33]. Therefore, high levels of stress could lead to the development of difficult temperament, presented with negative humour and maladaptive difficulties [33].

Other authors affirmed that their study did not show conclusive results, so a correlation between maternal stress and child temperament could not be clearly established [34].

\subsection{Memory and Learning}

A correlation between maternal stress and alterations in memory and learning abilities was described, because high levels of cortisol can affect the foetal hippocampus, decreasing neurogenesis and neuronal density [35].

Some researchers exposed memory alterations could have a bigger impact on girls, while boys could show improvements in maths and reading abilities [25].

When the correlation between this stress and visuospatial memory was studied, it was concluded that this kind of memory could be affected both in boys and girls [18].

\section{Discussion}

The main objective of this study was to determine whether a relation between maternal stress during pregnancy and neurodevelopment exists. Different investigations showed that this type of stress can affect different areas of neurodevelopment, such as cognitive development, motor development, behaviour, temperament, memory and learning. Numerous researchers who studied that relation determined that the alterations in neurodevelopment can be mainly due to modifications in the HPAA, in consequence of the increased levels of cortisol [7,14,17].

Regarding cognitive development, different investigators share the idea that maternal stress during the first half of gestation plays an important role in boosting alterations related to cognitive development $[9,10,18,21]$. Nevertheless, discrepancies exist amongst those investigations: some affirm that they would come up during the first years of life $[6,9,10,21]$, while others say the major consequences would appear later in life, around preadolescence [7]. Furthermore, some studies explain girls are more likely to suffer from those alterations $[18,19]$. However, other studies display completely different results, concluding stress does not always have to play a negative role in neurodevelopment and it could even be positive during the third trimester of gestation [23].

Moreover, a correlation between cognitive development and motor development was established, both being able to be influenced by stress suffered by the mother during gestation $[9,10]$. Even so, other experts do not establish this association, but they do say that this stress could modify motor development in children $[19,20,22]$.

Maternal stress can also affect child behaviour during childhood and adolescence [10,23]. Many studies share this conclusion and they also say behaviour changes will depend on the foetus' sex and the trimester of pregnancy when the stress shows $[10,25,28,30]$. This way, some studies explain these alterations would be more likely to appear on boys, whether the mother experienced stress at the beginning of gestation $[9,25]$ or at the end of it [28]. Therefore, it is not clear which period of foetal development would be more sensitive to stress. According to the foetal sex, boys could experience more problems related to hyperactivity and emotional problems, while girls could mainly only suffer from emotional problems [27]. However, there is not an agreement on which sex could be more likely to show behaviour changes. On one hand, some researchers affirm girls could be more vulnerable [32]; 
while on the other hand, other studies explain this could depend on the moment of pregnancy when the stress appears [10], with boys being more sensitive at the beginning and girls in the end [10].

In relation to behaviour, it is also important to focus on temperament $[9,10]$. This is the reason why its relation to stress was also studied. Many researches studied perceived stress by the mother, establishing a correlation between these stress levels and the development of a difficult temperament in children [9,32,33], mostly when it appears at the beginning of pregnancy [9]. Nevertheless, high cortisol levels measured during gestation can also boost a difficult temperament during the first year of life [10]. In spite of all of this, there are also studies that do not show conclusive results [34]. That is the reason why the correlation between stress during gestation and temperament alterations is not very clear yet.

Finally, maternal stress could also have a negative impact on memory and learning abilities. Some researchers showed that a long exposition of the foetus to high levels of glucocorticoids, mainly during the third trimester of pregnancy, could be correlated to learning problems in the future [10,24], because of an inappropriate hippocampus development due to a cortisol excess [35]. These learning problems could show up from 2 years old to 5 years old $[6,25]$. Nevertheless, some investigators studied the influence of this stress and memory and visuospatial learning, concluding there is not a correlation between them [9]. This explains that this association does not always exist.

Due to the important consequences maternal stress could cause on neurodevelopment, it would be advisable for health professionals who take care of women during their gestation to develop some strategies able to help to decrease this stress, especially during those periods in pregnancy when it could be worst for the foetus. Moreover, some researchers showed how important skin-to-skin contact is during the first months of life to diminish some of the alterations maternal stress could cause in the future $[29,30]$. Although establishing a mother-son bond could be difficult when mothers suffer from stress [31], this practice should be recommended amongst new mothers. Moreover, as was described previously, researchers propose different moments in pregnancy when the foetus could be more likely to suffer from alterations in neurodevelopment. They also propose differences related to sex-specific problems. Thus, future researchers following these topics would be interesting.

This study has some strengths: different areas of the neurodevelopment that could be affected by the action of stress were studied instead of just focusing on neurodevelopment as a whole. The anatomic and behavioural consequences of each one of them were described as well.

However, there are also some limitations: some research studies used for this study had fair quality, instead of good quality. This could affect the quality of the results shown here. Moreover, in some of the studies, general stress effects were studied, while pregnancy-specific stress or a mix of both types of stress were studied in other articles. This way, we are not able to know which alterations are specific to each type of stress.

\section{Conclusions}

There are many mechanisms that can be altered, both in general stress and in pregnancy-specific stress. They can have a direct and indirect influence on child neurodevelopment. It is not clear yet what mechanisms these are or how they can alter neurodevelopment. In this way, it was explained that stress during pregnancy can affect different areas in neurodevelopment. It is still unknown which of them would be more negatively affected or which foetal sex could be more vulnerable to show changes in them. More research following this line would be necessary to clarify these aspects.

Author Contributions: Conceptualization, C.M.-B. and R.A.C.-G.; methodology, C.M.-B. and R.A.C.-G.; investigation, C.M.-B.; writing-original draft preparation, C.M.-B.; writing-review and editing, C.M.-B. and R.A.C.-G.; supervision, R.A.C.-G. All authors have read and agreed to the published version of the manuscript.

Funding: This research received no external funding.

Conflicts of Interest: The author declares no conflict of interest. 


\section{References}

1. Schetter, C.; Tanner, L.; Angeles, L. Anxiety, depression and stress in pregnancy: Implications for mothers, children, research, and practice. Curr. Opin. Psychiatry 2015, 25, 141-148. [CrossRef]

2. American Institute of Stress. What Is Stress? 2019. Available online: https://www.stress.org/what-is-stress (accessed on 19 December 2019).

3. Connors, S.; Levitt, P.; Matthews, S.; Slotkin, T.A.; Johnston, M.V.; Kinney, H.C.; Johnson, W.G.; Dailey, R.M.; Zimmerman, A.W. Fetal Mechanisms in Neurodevelopmental Disorders. Pediatr. Neurol. 2008, 38, 163-176. [CrossRef] [PubMed]

4. Salihagic-Kadic, A.; Kurjak, A.; Medić, M.; Andonotopo, W.; Azumendi, G. New data about embryonic and fetal neurodevelopment and behavior obtained by 3D and 4D sonography. J. Perinat. Med. 2005, 33, 478-490. [CrossRef]

5. Cole-Lewis, H.J.; Kershaw, T.S.; Earnshaw, V.A.; Yonkers, K.A.; Lin, H.; Ickovics, J.R. Pregnancy-specific Stress, Preterm Birth, and Gestational Age Among High-risk Young Women. Health Psychol. 2014, 33, 1033-1045. [CrossRef] [PubMed]

6. $\quad$ Laplante, D.; Barr, R.; Brunet, A.; Du Fort, G.G.; Meaney, M.L.; Saucier, J.F.; Zelazo, P.R.; King, S. Stress during pregnancy affects general intellectual and language functioning in human toddlers. Pediatr. Res. 2004, 56, 400-410. [CrossRef] [PubMed]

7. Rakers, F.; Rupprecht, S.; Dreiling, M.; Bergmeier, C.; Witte, O.W.; Schwab, M. Transfer of maternal psychosocial stress to the fetus. Neurosci. Biobehav. Rev. 2016, 2016. [CrossRef] [PubMed]

8. Romero-Gonzalez, B.; Caparros-Gonzalez, R.; Gonzalez-Perez, R.; Delgado-Puertas, P.; Peralta-Ramirez, M.I. Newborn infants' hair cortisol levels reflect chronic maternal stress during pregnancy. PLoS ONE 2018, 13, e0200279. [CrossRef]

9. Buitelaar, J.K.; Huizink, A.C.; Mulder, E.J.; de Medina, P.G.R.; Visser, G.H.A. Prenatal stress and cognitive development and temperament in infants. Neurobiol. Aging 2003, 24 (Suppl. 1), 53-60. [CrossRef]

10. Graignic-Philippe, R.; Dayan, J.; Chokron, S.; Jacquet, A.Y.; Tordjman, S. Effects of prenatal stress on fetal and child development: A critical literature review. Neurosci. Biobehav. Rev. 2014, 43, 137-162. [CrossRef]

11. Moher, D.; Liberati, A.; Tetzlaff, J.; Altman, D.G.; The PRISMA Group. Preferred reporting items for systematic reviews and meta-analyses: The PRISMA statement. PLoS Med. 2009, 6. [CrossRef]

12. University of Dundee. Literature Searching: Advanced Searching: PICO 2020. Available online: https: //libguides.dundee.ac.uk/literaturesearching (accessed on 10 January 2020).

13. National Heart, Lung, and Blood Institute. Study Quality Assessment Tools. Available online: https: //www.nhlbi.nih.gov/health-topics/study-quality-assessment-tools (accessed on 10 January 2020).

14. Beijers, R.; Buitelaar, J.; de Weerth, C. Mechanisms underlying the effects of prenatal psychosocial stress on child outcomes: Beyond the HPA axis. Eur. Child Adolesc. Psychiatry 2014, 23, 943-956. [CrossRef] [PubMed]

15. Glover, V.; O'Donnell, K.; O'Connor, T.; Fisher, J. Prenatal maternal stress, fetal programming, and mechanisms underlying later psychopathology—A global perspective. Dev. Psychopathol. 2018, 30, 843-854. [CrossRef] [PubMed]

16. Jašarević, E.; Howerton, C.; Howard, C.; Bale, T.L. Alterations in the vaginal microbiome by maternal stress are associated with metabolic reprogramming of the offspring gut and brain. Endocrinology 2015, 156, 3265-3276. [CrossRef] [PubMed]

17. Lindsay, K.; Buss, C.; Wadhwa, P.; Entringer, S. The Interplay Between Nutrition and Stress in Pregnancy: Implications for Fetal Programming of Brain Development. Biol. Psychiatry 2019, 85, 135-149. [CrossRef]

18. Buss, C.; Davis, E.P.; Hobel, C.J.; Sandman, C.A. Maternal pregnancy-specific anxiety is associated with child executive function at 6-9 years age. Stress 2011, 14, 665-676. [CrossRef]

19. Andiarena, A.; Balluerka, N.; Murcia, M.; Ibarluzea, J.; Glover, V.; Vegas, O. Evening salivary cortisol and alpha-amylase at 14 months and neurodevelopment at 4 years: Sex differences. Horm. Behav. 2017, 94, 135-144. [CrossRef]

20. Kantonen, T.; Karlsson, L.; Nolvi, S.; Karukivi, M.; Tolvanen, M.; Karlsson, H. Maternal alexithymic traits, prenatal stress, and infant temperament. Infant Behav. Dev. 2015, 41, 12-16. [CrossRef]

21. Van den Bergh, B.R.H.; Van den Heuvel, M.; Lahti, M.; Braeken, M.; de Rooij, S.R.; Entringer, S.; Hoyer, D.; Roseboom, T.; Räikkönen, K.; King, S.; et al. Prenatal developmental origins of behavior and mental health: The influence of maternal stress in pregnancy. Neurosci. Biobehav. Rev. 2017, 2017. [CrossRef] 
22. Caparros-Gonzalez, R.; Romero-Gonzalez, B.; Gonzalez-Perez, R.; Lucena-Prieto, L.; Perez-Garcia, M.; Cruz-Quintana, F.; Peralta-Ramirez, M.I. Maternal and Neonatal Hair Cortisol Levels Are Associated with Infant Neurodevelopment at Six Months of Age. J. Clin. Med. 2019, 8, 2015. [CrossRef]

23. Phua, D.Y.; Kee, M.K.Z.L.; Koh, D.X.P.; Rifkin-Graboi, A.; Daniels, M.; Chen, H.; Chong, Y.S.; Broekman, B.F.P.; Magiati, I.; Karnani, N.; et al. Positive maternal mental health during pregnancy associated with specific forms of adaptive development in early childhood: Evidence from a longitudinal study. Dev. Psychopathol. 2017, 29, 1573-1587. [CrossRef]

24. Graham, A.; Rasmussen, J.; Entringer, S.; Ward, E.B.; Rudolph, M.D.; Gilmore, J.H.; Styner, M.; Wadhwa, P.D.; Fair, D.A.; Buss, C. Maternal Cortisol Concentrations During Pregnancy and Sex-Specific Associations With Neonatal Amygdala Connectivity and Emerging Internalizing Behaviors. Biol. Psychiatry 2019, 85, 172-181. [CrossRef] [PubMed]

25. Hamada, H.; Matthews, S. Prenatal programming of stress responsiveness and behaviours: Progress and perspectives. J. Neuroendocrinol. 2018, 31. [CrossRef] [PubMed]

26. Davis, E.; Sandman, C. Prenatal psychobiological predictors of anxiety risk in preadolescent children. Psychoneuroendocrinology 2012, 37, 1224-1233. [CrossRef] [PubMed]

27. Sejbaek, C.; Niclasen, J.; Bonde, J.; Kristensen, P.; Larsen, A.D.; Schlünssen, V.; Hougaard, K.S. Maternal exposure to psychosocial job strain during pregnancy and behavioral problems in the 11-year-old children: A Danish cohort study. Eur. Child Adolesc. Psychiatry 2020, 2020. [CrossRef]

28. Werner, E.; Zhao, Y.; Evans, L.; Kinsella, M.; Kurzius, L.; Altincatal, A.; McDonough, L.; Monk, C. Higher maternal prenatal cortisol and younger age predict greater infant reactivity to novelty at 4 months: An observation-based study. Dev. Psychobiol. 2013, 55, 707-718. [CrossRef]

29. Pickles, A.; Sharp, H.; Hellier, J.; Hill, J. Prenatal anxiety, maternal stroking in infancy, and symptoms of emotional and behavioral disorders at 3.5 years. Eur. Child Adolesc. Psychiatry 2017, 26, 325-334. [CrossRef]

30. Sharp, H.; Hill, J.; Hellier, J.; Pickles, A. Maternal antenatal anxiety, postnatal stroking and emotional problems in children: Outcomes predicted from pre- and postnatal programming hypotheses. Psychol. Med. 2015, 45, 269-283. [CrossRef]

31. Hernández-Martínez, C.; Voltas-Moreso, N.; Arija, V.; Piñana, C.J.; Carretero, C.B.; Canals, J. The role of maternal emotional states during pregnancy and early infancy on infant cortisol levels: A prospective study. Infant Child Dev. 2019, 28, 1-13. [CrossRef]

32. Baibazarova, E.; Van De Beek, C.; Cohen-Kettenis, P.; Buitelaar, J.; Shelton, K.H.; van Goozen, S.H.M. Influence of prenatal maternal stress, maternal plasma cortisol and cortisol in the amniotic fluid on birth outcomes and child temperament at 3 months. Psychoneuroendocrinology 2013, 38, 907-915. [CrossRef]

33. Blair, M.; Glynn, L.; Sandman, C.A.; Davis, E.P. Prenatal maternal anxiety and early childhood temperament. Stress 2011, 14, 644-651. [CrossRef]

34. McMahon, C.; Boivin, J.; Gibson, F.; Hammarberg, K.; Wynter, K.; Saunders, D.; Fisher, J. Pregnancy-specific anxiety, ART conception and infant temperament at 4 months post-partum. Hum. Reprod. 2013, 28, 997-1005. [CrossRef] [PubMed]

35. Richetto, J.; Riva, M. Prenatal maternal factors in the development of cognitive impairments in the offspring. J. Reprod. Immunol. 2014, 104-105, 20-25. [CrossRef] [PubMed]

Publisher's Note: MDPI stays neutral with regard to jurisdictional claims in published maps and institutional affiliations.

(C) 2020 by the authors. Licensee MDPI, Basel, Switzerland. This article is an open access article distributed under the terms and conditions of the Creative Commons Attribution (CC BY) license (http://creativecommons.org/licenses/by/4.0/). 